\title{
THE ECONOMIC IMPACT OF DIGITALISATION IN INDIAN SOCIAL AND EDUCATION SECTOR
}

\author{
Dr. Mohan Kumar K \\ Associate Professor of History, Government First Grade College Hosakote-562114
}

Article DOI: https://doi.org/10.36713/epra9297

DOI No: 10.36713/epra9297

\begin{abstract}
Digital technology is the usage of modern scientific technology and its implementation in most of the sectors, $e$ administration and the education sector can be the better example for this digitalisation. In the history of digitalisation we can find by sources that, most of the developed economies in the world were using digital technology from the pat decades, but developing countries in the world are using digital implementation a positive factor for sustainable development for the social development of a nation with good legal system in a country and leads to Indian economic growth and social development. Digitalisation benefits in e-education like conferences, MOOC (Massive Open Online Courses), Digital libraries can be taken as a better example for academic progress by the usage of digitalisation, In India digitalisation is playing a vital role from almost 1.5 years, because of lot of demand due to pandemic covid-19 and lockdown situation, India has to take a appositive steps to implementation of digitalisation in all public and private sectors for positive socialeconomic growth, for digital education, as koutilya mentioned economics and social-political system and law in Arthashastra.
\end{abstract}

\section{INTRODUCTION}

The digital infrastructure of India has helped us to provide e- governance and direct transfer services during covid19 pandemic with courts handling lakhs of cases through digital hearing. The e- committee was formed in 2004 to draw an action plan for ICT efficacy of the judiciary under the chairmanship (chief-cum - adhoc -chairman) of the chief justice of India .The cabinet committee of economic affairs (CCEA) first approved the e- courts project i.e., computerization of the Indian judiciary on $8^{\text {th }}$ February 2007. Covid 19 virus has played huge role in destruction of the social system of the countries, especially education sector was hard hit by the pandemic, management education was no way to run classes offline for almost half of 2020 and half of 2021 academic years, but nobody is sure about the next wave of the pandemic and the impact of it, cores of people lost their job opportunities and some private sector offices could sustain by adopting digital apps /applications in India, ex: Banking, education applications. The emergence of Covid-19 in India is a great concern for the social and economic history, as most of the political economies will not be able to perform the administration work in proper manner, so technical implementation to be improved in the country, posing challenge to the
Indian economy to resume the economic activities like education, business and growth, internally and externally.

\section{REVIEW OF LITERATURE \\ - E-LEANING Definition by Economic times:}

A learning system based on formalised teaching but with the help of electronic resources is known as Elearning. While teaching can be based in or out of the classrooms, the use of computers and the Internet forms the major component of E-learning. E-learning can also be termed as a network enabled transfer of skills and knowledge, and the delivery of education is made to a large number of recipients at the same or different times. Earlier, it was not accepted wholeheartedly as it was assumed that this system lacked the human element required in learning.

\section{- WTO}

The term "electronic commerce" is understood to mean the production, distribution, marketing, sale or delivery of goods and services by electronic means.

- The Arthashastra explanation by koutilya The Arthashastra explores issues of social welfare the collective ethics that hold a society together, advising the king that in times and in areas devastated by 
famine, epidemic and such acts of nature, or by war, he should initiate public projects such as creating irrigation waterways and building forts around major strategic holdings and towns and exempt taxes on those affected. The text was influential on other Hindu texts that followed, such as the sections on kings, governance and legal procedures included in Manusmriti.

\section{NEED OF THE STUDY}

1. Digital technology is very essential for the human resources and social-economical-political development.

2. To understand monetary and fiscal policies by the government and the educational policies towards improvement and growth of the colleges, institutions etc.

\section{STATEMENT OF PROBLEM}

Overall covid-19 has brought unsure in resuming demand and supply in economic and social activities in India, India is slowly gaining the importance of online education, e-commerce and egovernance, import of digital technology, from March 2020, the government of India has to offer more sops and opportunities for the manufacturers to innovate, produce globally efficient e- technology services in education, digital products of global standard, to increase the potential demand for self reliant India scheme through usage of e-commerce, flexible trade and transportation policies and technology, some problems have arised in the Indian economy like migration, unemployment, due to lack of digitalisation in some sectors.

\section{DATA AND STATISTICS}

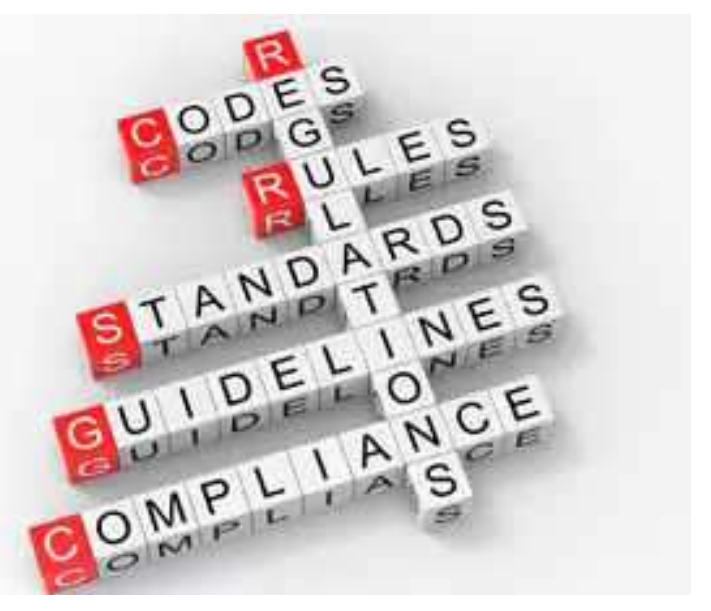

The data signifies the regularities, complaints, tandards and the rules and regulations, with codes, where greater the improvement,

\section{OBJECTIVES OF THE STUDY}

The novel Coronavirus has sent shock waves across the world causing mass suffering and deaths. Social distancing has been the mainstay for protection from spreading the COVID 19 and in view of this the Indian judiciary has take various steps. The SC (Supreme court) of India has laid the guidelines for the functioning of the court during the outbreak of covid19. The concept of Artificial Intelligence refers to computers or robots that are capable of doing all the tasks that require human intelligence. A combination of Artificial intelligence along with the law involves the use of computer and mathematical techniques to make the law more logical, convenient and simpler. The legal profession in India is more manual and more traditional, but after the outbreak of Covid19 the courts were closed the advocates had no other option rather to opt or artificial intelligence including the use of computers instead of typewriters and they had to online access for the citation of cases, websites like Manuptra had played an important role and an important source for the advocates.

\section{ADVANTAGES OF DIGITALISATION}

Automated billing: The artificial intelligence software helps in the preparation of invoices of the lawyers in steps with the work done by them. By this lawyers and law firms will simply interpret the precise amount of stipends bill of work done by the Practioner working under them

The Vision lays emphasis on the importance of guardrails and processes. There is, therefore, extensive focus on principles, be they of integrity, accountability, transparency, procurement. These lay an extremely strong foundation for an effective 
governance framework. The ideas propagated in the Vision can be enhanced with stakeholder participation and ownership. Adoption benefits of the vision are manifold, and impact each stakeholder group. Judges could benefit from other data, information and other decision making support that aids management of the case flow.

Analysis of legal document: Analysis of the legal document can be done easily with the help of Artificial Intelligence.

\section{FALLACIES OF THE DIGITALIZATION OF THE INDIAN JUDICIAL SYSTEM}

- Moreover, another practical and the most important problem which is that in India, there are 24 High courts. More than 600 District courts and other subordinate judicial institutions. The cost of setting up and installation would require a huge amount of investment. To convert the judicial system into a remote- working successful "Virtual" world, technological up-gradation and investment in court are quintessential.

- And Apart from this, one important aspect which gets unnoticed is that, speedier justice would result in deterioration of the quality of justice. For this we need to make sure that speedy delivery of justice doesn't cost us the efficiency and effectiveness of justice. Because if we want to have more effective judicial system, it is necessary to make technology accessible to everyone.

\section{CONCLUSION}

Indian government has announced some essential schemes like Make in India, and Start up India in recent years to increase in production, efficiency, output in domestic industries and other sectors, by implementation of digitalisation and artificial intelligence, but Covid-19 has made Indian government to announce 20.97 lakh core's economic stimulus package between March 26 and May 17, balancing demand and supply of oil, food grains, packages for unorganised sector workers has made Indian Economies growth to slow down, because lack of digital implementation, India has to rethink in investment and need innovative fiscal, monetary and social measures to overcome three challenges what India is facing. First one is to control or to overcome covid-19, which is health emergency. Second one is to increase in quality, quantity of output that is export value with promotion of digitalisation for achieving digital India. Third one is India to become global power in technical implementation in all the sectors that is primary, secondary and tertiary sectors like education, legal services, etc to overall increase in the flexibility of the nation.

\section{LIMITATION}

1 digitalisation are useful in the pandemic time, but over digitalisation can lead to clashes for job, because of more technology and less labour.

2 Technically speaking, online classes practically not $100 \%$ suitable for school and children education.

\section{REFERENCE}

1. CMIE (Centre for monitoring Indian economy), Bombay

2. EnergyWorld.com

3. https://www.statista.com/chart/18245/indiaquarterly-gdp-growth/

4. https://unemploymentinindia.cmie.com/https://w ww.gktoday.in/

5. WWW.WIKIPEDIA.COM

6. https://www.iacajournal.org/articles/10.36745/ij ca.391/

7. https://blog.ipleaders.in/covid-19-and-thereconditioning-of-the-indian-legal-system/ 